\title{
Influence of feeding on contracted tendons
}

\author{
H. F. Hintz
}

Department of Animal Science, Cornell University, Ithaca NY, USA

\begin{abstract}
Summary
Contracted tendons or flexural limb deformities can be congenital or acquired. The causes of congenital contracted tendons are not known but intrauterine positioning and disturbed fetal growth may be factors.

Acquired flexural deformities can involve the deep digital flexor or superficial digital flexor tendons. Several etiological factors have been suggested. Genetic predisposition for rapid growth or perhaps faulty conformation might be involved. Rapid growth resulting from excessive energy intake is frequently suggested as a major factor. Attempts to produce contracted tendons, however, by simply overfeeding are not always highly successful. We have produced a condition that appears to be similar to contracted tendons. Restricting intake of Thoroughbreds and Standardbreds starting at about four months of age for four months so that weight gains are about $10 \%$ of normal and then feeding ad libitum resulted in a high incidence of the condition. Similar studies with Arabians did not result in contracted tendons. Perhaps age of horse during the rapid growth phase and breed of horse may influence the effect of rate of gain.
\end{abstract}

Key words: $\quad$ contracted tendons, flexure deformities, horses, growth, skeleton

\begin{abstract}
Einfluß der Fütterung bei Sehnenkontrakturen
Sehnenkontrakturen oder flexurale Deformitäten der Gliedmaßen können sowohl kongenital als auch erworben sein. Ursachen kongenitaler Sehnenkontrakturen sind bislang unbekannt; die intrauterine Position des Fetus und ein gestörtes fetales Wachstum mögen hierbei eine Rolle spielen.

Erworbene Beugedeformitäten können sowohl die tiefe als auch die oberflächliche Zehenbeugesehne betreffen. Bislang wurden in diesem Zusammenhang mehrere ätiologische Faktoren genannt. Mitverantwortlich für das Auftreten dieses Krankheitsbildes können demnach eine genetische Prädisposition für schnelles Wachstum oder aber eine evt. fehlerhafte Anpassung sein. Als Hauptfaktor wird jedoch häufig ein gesteigertes Wachstum genannt, ausgelöst durch eine exzessive Energiezufuhr. Versuche, Sehnenkontrakturen durch Überfütterung herbeizuführen, erwiesen sich nicht immer als erfolgreich. Wir haben ein Krankheitsbild erzeugt, das dem der Sehnenkontraktur ähnlich erscheint. Eine viermonatige eingeschränkte Futteraufnahme führte bei 4 Monate alten Thoroughbreds und Standardbreds zu einem Gewichtszuwachs, der etwa $10 \%$ des normalen Gewichtzuwachses entsprach. Nach der anschließenden ad-libitum-Fütterung konnte ein gehäuftes Auftreten dieses Krankheitsbildes beobachtet werden. Bei ähnlichen Studien mit Arabern traten keine Sehnenkontrakturen auf. Es wird vermutet, daß das Alter des Pferdes in der Phase des stärksten Wachstums sowie die Rasse hinsichtlich des Effekts der Gewichtszunahme eine Rolle spielen.
\end{abstract}

Schlüsselwörter: Sehnenkontraktur, Beugedefomitäten, Pferde, Wachstum, Skelett

Contracted tendons (flexural limb deformities, flexure deformities) can be congenital or acquired. Uterine malpositioning is often cited as a cause of congenital flexure deformities. Stashak (1996) suggested that while malpositioning may be a leading cause, several other factors such as genetic predisposition, disturbed fetal growth during the embryonic state of pregnancy, and equine goiter may also be involved. Locoweed ingestion by pregnant mares has also been associated with congenital flexure deformities (Mcllwraith and James, 1982). Nutrition has seldom been implicated in congenital flexure deformity.

Acquired flexural deformity, however, has been frequently associated with malnutrition. Stashak (1996) concluded that the major nutritional imbalances related to musculoskeletal diseases in growing horses are a deficiencies or excesses of energy, protein, calcium, phosphorus, zinc or vitamins $D$ and $A$, and a deficiency of copper and manganese. Stashak (1996) suggested that the major effect of malnutrition is an interference with endochondral ossification which can result in a variety of malformations including angular limb deformities and acquired flexure deformities. Pain from wounds, epiphysitis or osteochondritis dissicans can cause an altered position of the joint (Stashak, 1996). Thompson et al. (1988 b) reported that rapid growth was associated with epiphysitis and Stashak (1996) suggested that many horses with epiphysitis have flexure deformities. Thompson et al. (1988a) reported that skeletal development as measured by cortical area may be compromised by a high rate of growth. Hintz and Kallfelz (1981) reported case histories of foals with flexure deformities which were fed high grain intakes.

Cymbaluk et al. (1990) fed eighteen colts limited or ad libitum for 18 months. The limited fed foals gained $195 \mathrm{~kg}$ whereas the ad libitum fed foals gained $243 \mathrm{~kg}$. Five of the nine horses 
fed ad libitum had forward buckling of the carpus or fetlock during stance.

Other factors must be involved because above average growth rate does not always cause flexural deformities. In fact, many rapidly growing horses do not develop flexural deformities. Thompson et al. (1988c) weaned foals at an average of 105 days of age and fed two levels of energy for 215 days. Normal-fed foals gained $105 \mathrm{~kg}$ whereas the "overfedfoals" gained $144 \mathrm{~kg}$. No dietary effect on incidence of flexural deformities was evident.

We suggested that the age of the foal during the rapid growth phase and the previous growth history could be factors (Hintz et al., 1976). Nine weanlings and six yearlings were purchased from one owner. The weanlings were in excellent flesh but the yearlings were unthrifty, heavily parasitized and small for their age. All the horses were dewormed and then fed ad libitum a diet containing $2.8 \mathrm{mcal} / \mathrm{kg}$. No difficulties were experienced with the weanlings. The yearlings gained weight rapidly but within one or two months, four of the six developed very straight limbs in which the fetlock joint was more upright than normal. In two of the animals the condition became so severe that the fetlock joint flexed forward during the later part of the support phase of the gait. It was thought that the development of this condition which seemed to be identical to "contracted tendons" was related to the restriction of growth and subsequent rapid growth. Therefore, a study was conducted to determine if a contracted tendons could be induced by manipulation of rate of gain.

Twelve Standardbred foals were weaned at 4 months of age and were randomly assigned to one of two groups. 1. Ad libitum feed for eight months, 2. Restricted feed for four months and then fed ad libitum for four months. The foals were weighed weekly and feed intake adjusted for the animals in the restricted group such that average daily gain did not exceed $0.3 \mathrm{~kg}$. The animals were fed individually and feed intake recorded. Height at the withers and cannon bone circumference at the midpoint were measured monthly. The pelleted diet consisted of $35 \%$ alfalfa meal, $48 \%$ corn, $15 \%$ soybean meal, $1 \%$ trace mineral salt and $1 \%$ dicalcium phosphate. It contained $89 \%$ dry matter, $17 \%$ crude protein, $0.9 \%$ calcium and $0.55 \%$ phosphorus. The ad libitum foals gained $0.85 \mathrm{~kg} /$ day. The second group gained $0.23 \mathrm{~kg} /$ day when restricted and $0.81 \mathrm{~kg} /$ day during the ad libitum period. The average weight gain of the restricted foals during the period when they were fed ad libitum (months 5 through 8 of the experiment) was not different from the average gains of the ad libitum fed foals.

No skeletal abnormalities were observed in the ad libitum fed foals but four of the six restricted foals developed flexure deformity within one to three months after being fed ad libitum. The conditions were not as severe as those described above.

We then conducted a similar trial with Thoroughbred foals. The results were similar.
Restriction of feed intake for four months followed by ad libitum intake resulted in flexure deformities.

However, in a study with Arabians, reduced rate of gain followed by rapid gain did not result in flexure deformity (Schryver et al., 1987). One group of Arabian foals were fed a diet containing $9 \%$ protein for 140 days gained an average of $0.06 \mathrm{~kg} /$ day. They were then changed to a diet containing $20 \%$ protein. The average daily gain for the next 140 days was $1.0 \mathrm{~kg} /$ day. However, in contrast to the studies with Standardbreds and Thoroughbred foals none of the Arabian foals developed flexure deformity.

The Arabian foals fed $14 \%$ or $20 \%$ protein throughout the study gained $0.63 \mathrm{~kg}$ and $0.69 \mathrm{~kg}$ respectively during the first 140 days, and $0.64 \mathrm{~kg}$ and $0.64 \mathrm{~kg}$, respectively during the second 140 day period. Thus, even though the restricted Arabian foals gained at a greater rate than the unrestricted Arabian foals during the second period they did not develop flexural problems. The difference in response by the Arabians from that of Standardbreds and Thoroughbreds suggests that breed differences may be involved.

\section{References}

Cymbaluk, N. F., Christison, G. I. and Leach, D. H. (1990): Longitudinal growth analysis of horses following limited and ad libitum feeding. Equine Vet. J. 22, 198-204.

Hintz, H. F. and Kallfelz, F. A. (1981): Some nutritional problems of horses. Equine Vet. J. 13, 183-186.

Hintz, H. F.,. Schryver, H. F and Lowe, J. E. (1976): Delayed growth response and limb conformation in young horses. Proc. Cornell Nutr. Conf. for Feed Manuf., 94-97.

Mcllwraith, C. W. and James, L. F. (1982): Limb deformities in foals associated with ingestion of locoweed by mares. J. Am. Vet. Med. Assoc., 181, 255-258.

Schryver, H. F.,. Meakim, D. W, Lowe, J. E. and Hintz, H. F. (1987): Growth and calcium metabolism in horses fed varying levels of protein. Equine Vet. J., 19, 280-287.

Stashak, T. S. (1996): Horseowners guide to lameness. Williams and Wilkins, pp. 164.

Thompson, K. N., Jackson, S. G. and. Baker, J. P (1988 a): The influence of high planes of nutrition skeletal development of weanling horses. J. Anim. Sci., 66, 2459-2467.

Thompson, K. N., Jackson, S. G. and Rooney, J. R. (1988 b): The effect of above average weight gains on the incidence of radiographic bone aberrations and epiphysitis in growing horses. J. Equine Vet. Sci. 8, 383-385.

Thompson, K. N., Jackson, S. G., Roone, J. R. and Baker, J. P. (1988 c): Influence of confinement, plane of nutrition and low heel on the occurrence of acquired forelimb contracture in weanling horses. J. Equine Vet. Sci. 8, 386-391.

H. F. Hintz

Department of Animal Science

Cornell University

Ithaca NY 14853-4801 USA 